\title{
Conducta estral circanual en ovejas Pelibuey bajo condiciones áridas del noroeste de México
}

\section{Circannual estrous behavior in Pelibuey ewes under arid conditions of Northwestern of Mexico}

\author{
Miguel A. Gastelum-Delgadoa, Leonel Avendaño-Reyesa, Francisco D. Álvarez- \\ Valenzuelaa, Abelardo Correa-Calderóna, César A. Meza-Herrerab, Miguel Melladoc, \\ Ulises Macías-Cruza
}

\begin{abstract}
RESUMEN
Con el objetivo de determinar la conducta estral circanual de ovejas Pelibuey bajo condiciones áridas del noroeste de México (320 LN), 22 ovejas adultas se mantuvieron en condiciones estabuladas con una alimentación constante durante un año. Diariamente, mañana y tarde, el grupo de ovejas fue expuesto a uno de tres machos provistos de mandil para detectar estro. El porcentaje de ovejas en estro y su duración se calcularon en forma mensual. Las medias anuales de temperatura, humedad relativa e índice de temperatura-humedad fueron de $25.8 \pm 8.4$-C $33.1 \pm 11.2 \%$ y $72.0 \pm 8.8$ unidades, respectivamente. El porcentaje mensual de ovejas en estro fue menor $(P<0.05)$ de enero a junio que de julio a diciembre. El $100 \%$ de las ovejas presentaron estro en cada mes de julio a diciembre (P>0.05). Comparado con el resto de los meses; un mayor $(\mathrm{P}<0.05)$ porcentaje de ovejas mostraron estros cortos $(<24 \mathrm{~h})$ en febrero y marzo, y contrariamente, la proporción de ovejas con estros largos $(>36$ y $<48 \mathrm{~h})$ fue mayor $(\mathrm{P}<0.05)$ en junio y agosto. En conclusión, en condiciones áridas del noroeste de México, las ovejas Pelibuey disminuyen su actividad estral de enero a junio, y las elevadas temperaturas ambientales de verano no son un factor que afecte la presencia de estro en dicha raza.
\end{abstract}

PALABRAS CLAVE: Ovinos de pelo, Actividad reproductiva, Estro, Estrés calórico.

\begin{abstract}
In order to determine the circannual estrus behavior of Pelibuey ewes under arid conditions of Northwestern Mexico ( $320 \mathrm{NL}), 22$ adult ewes were maintained in confinement conditions with constant feeding during one year. Daily, morning and afternoon, the ewe group was exposed to one of three ram fitted with an apron to detect estrus behavior. Annual averages of temperature, relative humidity and temperature-humidity index were $25.3 \pm 8.1 \mathrm{oC}$, $33.1 \pm 10.7 \%$ and $72.0 \pm 8.4$ units, respectively. Monthly percentage of ewes in estrus was lower $(P<0.05)$ from January to J une than from July to December. The $100 \%$ of ewes showed estrus signs in each month from July to December $(P>0.05)$. Compared with others months, a higher $(P<0.05)$ percentage of ewes showed shorter estrus $(<24 \mathrm{~h})$ in February and March, contrarily, the proportion of ewes with longer estrus ( $>36$ and $<48$ h) was higher $(P<0.05)$ in June and August. In conclusion, under arid-dry conditions of Northwestern Mexico, Pelibuey ewes decrease their estrus activity from J anuary to J une, and high environmental temperatures of summer are not a factor affecting the estrus presence in this sheep breed.
\end{abstract}

KEY WORDS: Hair sheep, Reproductive activity, Estrus Heat stress.

Los ovinos se caracterizan por presentar una actividad reproductiva estacional a través del
Sheep are characterized by a seasonal reproductive activity throughout the year, being

\footnotetext{
Recibido el 6 de noviembre de 2012. Aceptado el 23 abril 2013.

a Instituto de Ciencias Agrícolas, Universidad Autónoma de Baja California, Mexicali, B.C., 21705, México. ulisesmacias1988@hotmail.com. Correspondencia al último autor.

b Unidad Regional Universitaria de Zonas Áridas, Universidad Autónoma Chapingo, Durango, México.

c Departamento de Nutrición Animal, Universidad Autónoma Agraria “Antonio Narro”, Coahuila, México.

Financiamiento: Esta investigación fue financiada a Ulises Macías Cruz dentro de la convocatoria "Apoyo a la Incorporación de Nuevos PTC-PROMEP 2010"
} 
año, siendo en la época donde predominan días cortos (otoño-invierno) cuando esta especie tiene actividad estral en forma regular(1). En este sentido, el fotoperiodo es el factor principal que regula la actividad reproductiva de los ovinos, aunque indirectamente otros factores ambientales también la afectan, tales como: disponibilidad de alimento, temperatura y humedad ambiental(2). El fenómeno de estacionalidad reproductiva es más marcado en razas de lana que en las de pelo(3). En estudios realizados en el noreste de México(4) y en el altiplano mexicano(5) con ovinos Pelibuey, reportaron que estos ovinos se caracterizan por presentar actividad reproductiva todo el año, con una disminución en el porcentaje de ovejas en estro entre los meses de enero a mayo, sin considerarse una época de anestro profundo como en las razas de lana.

En el noroeste de México, los ovinos de raza de pelo, como los Pelibuey y Dorper, son preferidos por los productores debido a su gran capacidad reproductiva y de adaptación a las condiciones climáticas extremosas que predominan en la región (hasta $500 \mathrm{C}$ en verano y bajo 0 ㅇ $\mathrm{C}$ en invierno)(6). Sin embargo, su conducta estral a través del año no ha sido evaluada bajo estas condiciones climáticas y latitudes. La mayor latitud y las altas temperaturas registradas durante verano son factores que pueden provocar una conducta reproductiva circanual diferente a la que presentan dichas ovejas en regiones del sur o centro del país. Se conoce que el fenómeno de estacionalidad reproductiva en ovejas se hace más evidente a medida que los animales se ubican a latitudes más lejanas del ecuador(3). Por otra parte, las condiciones ambientales de estrés calórico afectan directamente la presencia y duración del estro en los rebaños de ovinos debido a un bajo crecimiento del folículo dominante y reducidas concentraciones de hormona liberadora de gonadotropinas y hormona luteinizante, lo cual se refleja en una menor síntesis de estrógenos(7). Por lo tanto, el objetivo de este estudio fue determinar la conducta estral circanual de ovejas multíparas Pelibuey bajo short days (autumn-winter) when this species have estrous activity on a regular basis(1). In this sense, the photoperiod is the main factor that regulates the reproductive activity of sheep, although indirectly other environmental factors also affect it, such as: food availability, temperature and humidity(2). The phenomenon of reproductive seasonality is more pronounced in wool breeds than in hair breeds(3). In studies carried out in the Northeast of Mexico(4), and in the Mexican Highlands(5) with Pelibuey breed sheep, reported that these sheep are characterized by present reproductive activity throughout the year, with a decrease in the percentage of ewes in estrous between months of J anuary to May, without considering a period of deep anestrous as in the wool breeds.

In the Northwestern of Mexico, hair breed sheep, as the Pelibuey and Dorper, are preferred by producers due to its high reproductive capacity and adaptation to extreme weather conditions prevailing in the region (up to $50^{\circ} \mathrm{C}$ in summer and below $0{ }^{\circ} \mathrm{C}$ in winter)(6). However, their estrous behavior throughout the year has not been evaluated under these conditions and latitudes. The greater latitude and high temperatures recorded in summer are factors that can cause a circannual reproductive behavior different from sheep in the South or Midwest regions. It is known that the phenomenon of reproductive seasonality in sheep is most evident when animals are located at latitudes farther from the Equator(3). On the other hand, environmental conditions of heat stress directly affect the presence and estrus duration in sheep flocks due to a low growth of the dominant follicle and reduced concentrations of gonadotropin releasing hormone and luteinizing hormone, which is reflected in a lower synthesis of estrogens (7). Therefore, the objective of this study was to determine the estrous circannual behavior in multiparous Pelibuey ewes under environmental conditions of the Northwestern of Mexico.

The study was conducted from January 1 to December 31, 2011 at the Institute of 
las condiciones ambientales del noroeste de México.

El estudio se llevó acabo del 1 de enero al 31 de diciembre del 2011 en el Instituto de Ciencias Agrícolas, de la Universidad Autónoma de Baja California (UABC), el cual se localiza en el Valle de Mexicali, a una latitud norte de 32ㅇ 24' y una longitud oeste de 1150 12'. El clima en esta región se caracteriza por ser árido y seco, muy similar a las condiciones del Desierto de Sonora(8).

Se utilizaron 22 ovejas adultas de raza Pelibuey, no lactantes, con $45 \mathrm{~d}$ de post-destete y nacidas en la región del estudio. Al inicio del experimento, las ovejas tenían una edad de entre 4 y 5 años, un peso vivo promedio de $51.3 \pm 4.8 \mathrm{~kg}$ y una condición corporal en escala de 1 a 5 de $3.1 \pm 0.2$ unidades(9). Las ovejas se mantuvieron en condiciones estabuladas en un solo corral de $6.0 \times 6.0 \mathrm{~m}$ provisto de comedero ( $0.5 \mathrm{~m} /$ animal), bebedero y sombra $\left(0.6 \mathrm{~m}^{2}\right)$. Las paredes del corral eran de malla metálica para garantizar un correcto flujo del aire, mientras que el techo estaba construido de lámina galvanizada en el centro del corral, a una altura de $2.5 \mathrm{~m}$. Desde un mes antes del estudio hasta su finalización, la alimentación fue constante y ad libitum con una dieta formulada con $48 \%$ de paja de trigo picada, $48 \%$ de heno de alfalfa molido y $4 \%$ de pre-mezcla mineral. La dieta contenía $91.2 \%$ de materia seca (MS), $9.8 \%$ de PC y $1.8 \mathrm{Mcal}$ de energía metabolizable/kg de MS. El agua se ofreció a libre acceso. Cabe mencionar, que un mes antes del inicio del experimento, todas las ovejas se trataron con $3.0 \mathrm{ml}$ de vitaminas A-D-E (Vigantol, Laboratorio Bayer, México), y $1.0 \mathrm{ml}$ del desparasitante ivermectina (Ivermectin, laboratorio Sanfer, México).

La temperatura ambiental ( $T$ ) y la humedad relativa (HR) diaria registrada durante el periodo de estudio se colectó de la Estación Meteorológica de la UABC. Con esta información climática se calculó el índice de temperaturahumedad (ITH) usando la siguiente fórmula(10):
Agricultural Sciences of the Autonomous University of Baja California (UABC), which is located in the Mexicali Valley, at a north latitude of $32^{\circ} 24^{\prime}$ and a west longitude $115^{\circ} 12^{\prime}$. The climate in this region is arid and dry, very similar to the conditions of the Sonoran Desert(8).

Twenty two (22) adult Pelibuey sheep, not lactating, with $45 \mathrm{~d}$ post-weaning and born in the region of the study, were used. At the beginning of the experiment, the sheep were 4 to $5 \mathrm{yr}$ of age, an average live weight of $51.3 \pm 4.8 \mathrm{~kg}$ and a body condition of $3.1 \pm$ 0.2 units on a scale of 1 to $5(9)$. The sheep were kept in confined conditions in a single pen of $6.0 \times 6.0 \mathrm{~m}$ equipped with feed troughs ( $0.5 \mathrm{~m} /$ animal), drinking troughs and shadow $\left(0.6 \mathrm{~m}^{2}\right)$. The pen walls were metal mesh to ensure a correct air flow, while the roof was built of galvanized sheet in the center of the corral, at a height of $2.5 \mathrm{~m}$. From one month before the study until its completion, feeding was constant and ad libitum with a diet formulated with $48 \%$ of chopped wheat straw, $48 \%$ of ground alfalfa hay and $4 \%$ mineral pre-mix. The diet contained $91.2 \%$ of dry matter (DM), $9.8 \%$ of crude protein (CP) and 1.8 Mcal of metabolizable energy / $\mathrm{kg}$ of DM. Water was offered free access. It is noteworthy, that a month before the start of the experiment, all the ewes were treated with $3.0 \mathrm{ml}$ of vitamin A-D-E (Vigantol laboratory Bayer, Mexico), and $1.0 \mathrm{ml}$ of the ivermectin deworming (Ivermectin, laboratory Sanfer, Mexico).

Ambient temperature $(T)$ and relative humidity $(\mathrm{RH})$ were registered daily during the study period, collected from the meteorological station of the UABC. With this climatic information, temperature-humidity index (THI) was calculated using the following formula(10): $\mathrm{THI}=(0.81 \mathrm{x}$ $\mathrm{T})+\mathrm{RH}(\mathrm{T}-14.4)+46.4$. Monthly averages of daily temperature, relative humidity and THI were registered. In addition, monthly averages of maximum and minimum for each climate factor; individual live weight and body condition were also recorded monthly for each ewe. 
$\mathrm{ITH}=(0.81 \times \mathrm{T})+\mathrm{HR}(\mathrm{T}-14.4)+46.4$. Medias mensuales de temperatura, humedad relativa e ITH diarios fueron calculados. Asimismo, promedios mensuales de máximas y mínimas de cada factor climático. Adicionalmente, el peso vivo y la condición corporal individual se registraron mensualmente para cada oveja.

La presencia de ovejas en estro también se midió diariamente durante 30 min en la mañana (0700 h) y $30 \mathrm{~min}$ en la tarde (1900 h) para determinar el porcentaje mensual de ovejas en estro y la duración de éste. Se utilizaron tres machos Pelibuey a través de todo el estudio para la detección de conducta de estro, los cuales permanecieron en un corral que se encontraba enfrente de donde estaban las hembras desde un mes antes de iniciar el experimento. Se consideró que una oveja estaba en estro cuando aceptaba la monta de un macho provisto de un mandil sin ningún reflejo de movimiento. Las ovejas detectadas en estro se colocaban en un corral adyacente y al finalizar el periodo de detección se regresaban al grupo. La detección de estro para cada oveja se realizó en forma repetida hasta que ya no aceptó la monta del macho, esto con el fin de poder determinar su duración. Solamente la duración de un estro por mes de cada oveja se evaluó para duración, y se seleccionó aquél que fue producto de un ciclo estral completo desarrollado en el mismo mes. Como la metodología usada para detectar estro impidió calcular el tiempo exacto que duró éste en cada oveja, se decidió estimar la duración del estro distribuyendo en cada mes a las ovejas dentro de tres categorías de tiempo ( $<24 \mathrm{~h}$ [estro corto], $>24$ y $<36 \mathrm{~h}$ [estro normal] y, $>36 \mathrm{y}<48 \mathrm{~h}$ [estro largo]). Las ovejas se clasificaron en las categorías de tiempo a partir de la frecuencia con que presentaron signos de estro en forma continua cada $12 \mathrm{~h}$ : dos veces $=<24 \mathrm{~h}$, tres veces $=>24$ $\mathrm{y}<36 \mathrm{~h}$, y cuatro veces $=>36 \mathrm{y}<48 \mathrm{~h}$.

El peso vivo y la condición corporal se analizaron bajo un diseño completamente al azar, usando el mes del año como tratamiento. Adicionalmente,
The presence of ewes in estrous was also measured daily by $30 \mathrm{~min}$ in the morning $(0700$ h) and $30 \mathrm{~min}$ in the afternoon (1900 h) to determine the monthly percentage of ewes in estrous and the estrous duration. Three Pelibuey rams were used throughout the study for estrous behavior detection, which remained in a pen that was in front opposite of the females, from one month before starting the experiment. A sheep was considered in oestrus when she accepted the mating of a male fitted with an apron without any reflection of movement. Ewes detected in estrous were placed in an adjacent pen, and at the end of the detection period, were returned to the group. In order to be able to determine estrous duration, estrus detection was performed repeatedly until ewes did not accept mating of the ram. Only the duration of an estrous per month in each ewe was evaluated for duration, being an estrous selected from of a full estrous cycle developed in the same month. As the methodology used to detect estrous prevented to calculate the exact time that this lasted in each ewe, it was decided to estimate estrus duration distributing in each month the ewes into three categories of time ( $<24 \mathrm{~h}$ [short estrous], $>24$ and $<36 \mathrm{~h}$ [normal estrous] and, $>36$ and $<48 \mathrm{~h}$ [long estrous]). The sheep were classified into the categories of time from the frequency with which presented signs of estrous continuously every $12 \mathrm{~h}$ : twice= $<24 \mathrm{~h}$, three times $=>24$ and $<36 \mathrm{~h}$, and four times $=>36$ and $<48 \mathrm{~h}$.

Live weight and body condition were analyzed under a completely randomized design, using the month of the year as treatment. Additionally, comparisons of means applying the Tukey test were made at $P<0.05$. The percentage of ewes in estrous per month was compared using the Chi-square test. In addition, in each month, the ewes with signs of estrous were distributed in three duration periods $<24 \mathrm{~h},>24$ and $<36$ $h$, and $>36$ and $<48$ h) and were compared with the Fisher's exact test. All statistical analyses were conducted using the statistical SAS package(11). 
se hicieron comparaciones de medias aplicando la prueba de Tukey a una $\mathrm{P}<0.05$. El porcentaje de ovejas en estro en cada mes se comparó usando la prueba de Ji-cuadrada. Además, en cada mes, las ovejas con signos de estro se distribuyeron en tres tiempos de duración $(<24$ $\mathrm{h},>24$ y $<36 \mathrm{~h}, \mathrm{y}>36$ y $<48 \mathrm{~h})$ y se compararon con la prueba exacta de Fisher. Todos los análisis estadísticos se realizaron utilizando el paquete estadístico SAS(11).

Las condiciones climáticas registradas en el año de estudio se presentan en las Figuras 1, 2 y 3. El promedio de temperatura, humedad relativa e ITH para todo el año fue de $25.8 \pm$ 8.4 으, $33.1 \pm 11.2 \%$ y $72.0 \pm 8.8$ unidades, respectivamente. En los meses de verano prevaleció una temperatura promedio alta ( 32.8 a $36.7 \stackrel{\circ}{\circ})$, lo cual conllevó a un incremento en los niveles de ITH (79.3 a 84.4 unidades). En el resto de los meses, la temperatura promedio se mantuvo por debajo de los $28 \stackrel{\circ}{ } \mathrm{C}$, asimismo el ITH fue menor a las 72 unidades. Esto significa que las ovejas estuvieron en un ambiente de estrés por calor en verano, considerando el índice de estrés señalado por los Índices de Estrés Calórico de Ganado y Aves (LPHSI por sus siglas en inglés)(12) (>72

Figura 2. Humedad relativa promedio, máxima y mínima mensual registrada durante el estudio

Figure 2. Monthly average, maximum and minimum of relative humidity recorded during the study

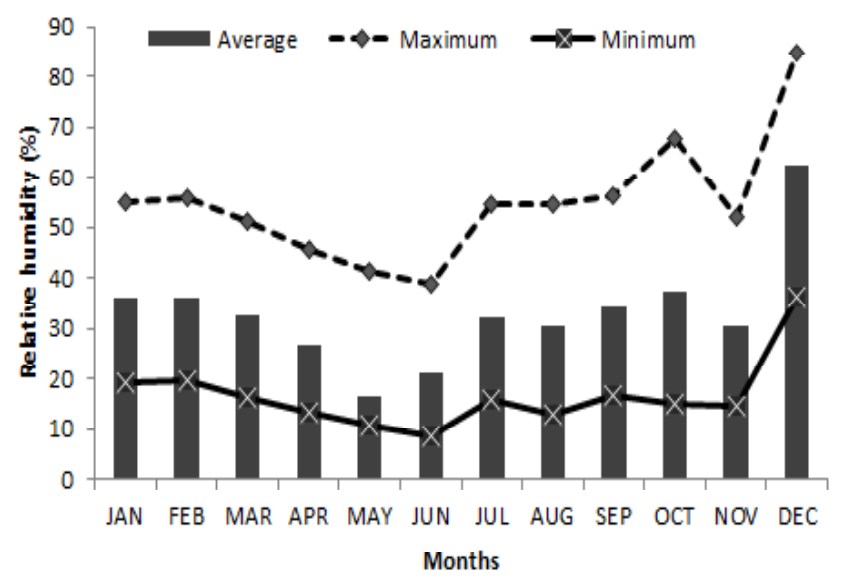

The weather conditions recorded in the year of study are presented in Figures 1, 2 and 3. The temperature, relative humidity and $\mathrm{THI}$ yearround averaged $25.8 \pm 8.4^{\circ} \mathrm{C}, 33.1 \pm 11.2 \%$ and $720 \pm 8.8$ units, respectively. In summer months prevailed a high average temperature (32.8 to $36.7^{\circ} \mathrm{C}$ ), which led to an increase in

Figura 1. Temperaturas promedios, máximas y mínimas mensuales registrada durante el estudio

Figure 1. Monthly average, maximum and minimum of temperature recorded during the study

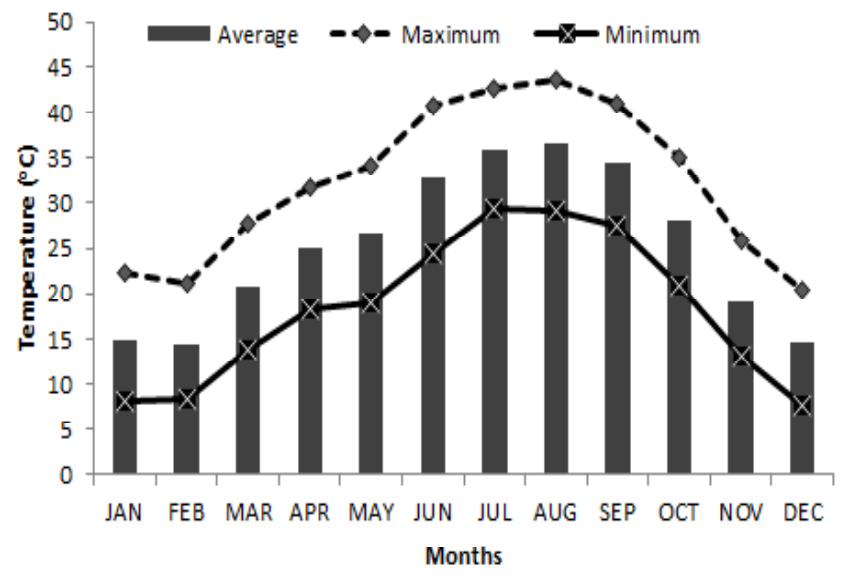

Figura 3. Índice de temperatura-humedad (ITH) promedio, máximo y mínimo mensual registrado durante el estudio

Figure 3. Monthly average, maximum and minimum of the temperature-humidity index (THI) recorded during the study

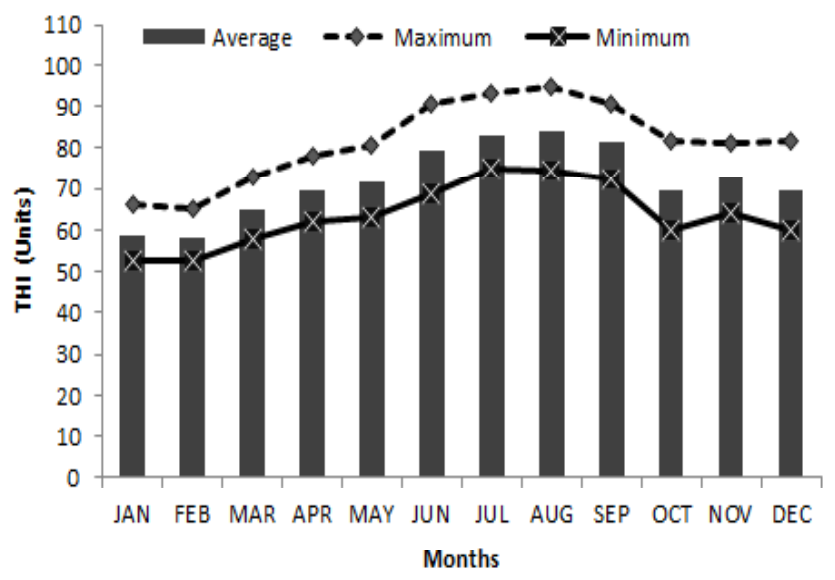


unidades inician los síntomas de estrés por calor). Aunque cabe mencionar que dicho índice no es apropiado para ovinos; sin embargo, hasta el momento no se ha desarrollado uno específico para dicha especie.

El peso vivo y la condición corporal de las ovejas incrementó $2.6 \mathrm{~kg}$ y 0.2 unidades, respectivamente, a través del año de estudio (Figura 4); sin embargo, no se observaron diferencias significativas $(P>0.05)$ entre los meses para ninguna de las variables. Esto sugiere que la conducta estral circanual observada en las ovejas Pelibuey bajo las condiciones áridas del noroeste de México, fue independiente del estado corporal que presentan las ovejas. Estudios previos han demostrado que la condición corporal no es un factor que predisponga la actividad estral de esta raza de ovinos $(13,14)$.

El porcentaje de ovejas en estro varió significativamente $(P<0.05)$ a través de los meses del año (Figura 5). El porcentaje de ovejas en estro fue menor $(P<0.05)$ de enero a junio (45.4 a $81.8 \%$ ) que de julio a diciembre

Figura 4. Peso vivo (LW) y condición corporal (BC) mensual de las ovejas Pelibuey durante el estudio (medias \pm desviación estándar)

Figure 4. Monthly live weight (LW) and body condition (BC) of Pelibuey ewes during the study (means \pm standard deviation)

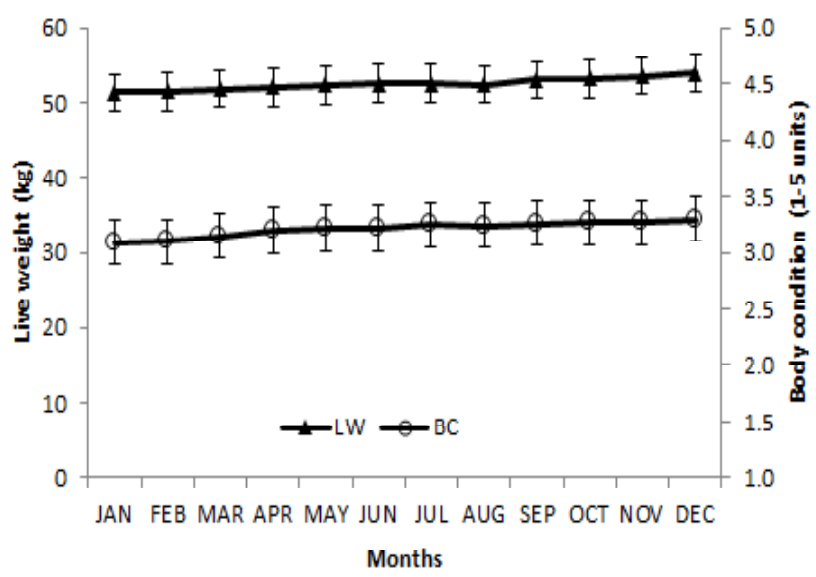

the levels of THI (79.3 to 84.4 units). In the rest of months, average temperatures remained below $28{ }^{\circ} \mathrm{C}$, likewise, THI was also less than the 72 units. This means that ewes were in an heat stress environment during summer, considering the stress index indicated by Livestock and Poultry Heat Stress Indices

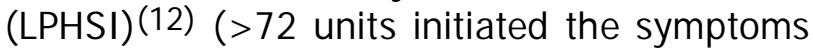
of heat stress). Although it is worth mentioning that this index is not suitable for sheep; however, so far it has not been developed a specific index to this species.

The live weight and body condition of the sheep increased $2.6 \mathrm{~kg}$ and 0.2 units, respectively, through the year of study (Figure 4), however, no significant differences were observed ( $P>0.05)$ among the months for any of the variables. This suggests that the circannual estrous behavior observed in Pelibuey ewes under arid conditions of the Northwestern of Mexico, was independent of the body status. Previous studies have shown that body condition is not a factor that predisposes the estrous activity of this sheep $\operatorname{breed}(13,14)$.

The percentage of ewes in estrous varied significantly $(\mathrm{P}<0.05)$ on months of the year

Figura 5. Conducta de estro mensual de ovejas de pelo $(\mathrm{N}=22)$

Figure 5. Monthly estrous behavior of Pelibuey ewes $(\mathrm{N}=22)$

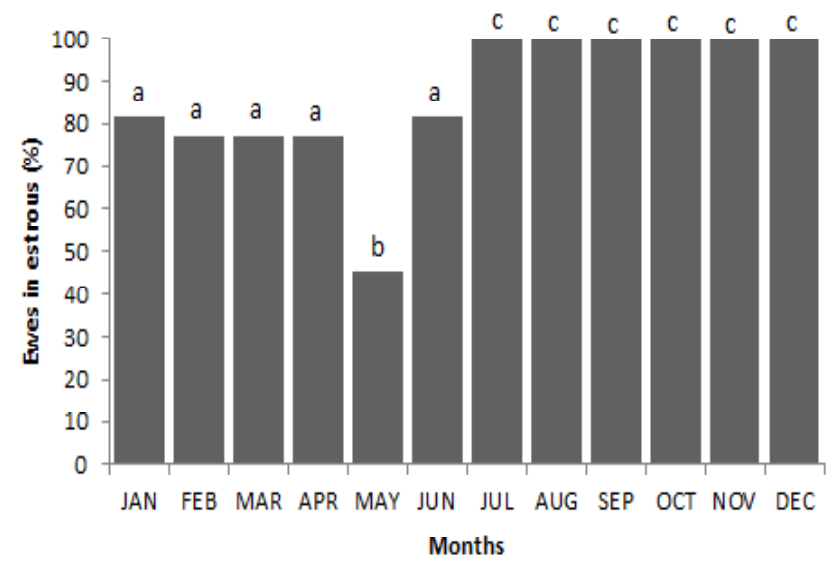


(100 \%). En mayo se detectó la presencia de ovejas en estro más baja $(P<0.05 ; 45.4 \%)$. De forma similar, estudios realizados al sur(14), centro(5) y noreste de México(4), han reportado una reducción en la actividad estral de ovejas Pelibuey entre los meses de enero a junio, siendo más marcada en la época de primavera. Los resultados encontrados en el presente estudio de actividad estral en la primera mitad del año, puede estar relacionada directamente con la sensibilidad que pueden presentar algunas ovejas Pelibuey a los cambios en el fotoperiodo $(14,15)$. Además, se debe considerar que los estudios publicados previamente se realizaron en regiones donde la latitud era menor a la que tenía la región donde se desarrolló el presente trabajo. Una hipótesis a probar en este estudio era que, las altas temperaturas de verano registradas en el noroeste de México podrían ser un factor que alteraran negativamente la conducta de estro en las ovejas Pelibuey, sin embargo, los resultados demuestran que dicha hipótesis es falsa, ya que $100 \%$ de las ovejas presentaron estro de julio a septiembre. Por lo tanto, se confirma lo señalado por De La Isla et al(14), que las temperaturas elevadas no son un factor ambiental que condicione la actividad estral en ovejas Pelibuey.

Cabe mencionar que existe una variación muy marcada entre estudios sobre el porcentaje de ovejas Pelibuey que presentan anestro durante la época de baja actividad reproductiva. En el altiplano Mexicano reportaron entre 0 y $23.1 \%$ de ovejas adultas en anestro(16), al noreste de país encontraron entre 42 y $76 \%$ de ovejas anéstricas $(4)$, y recientemente, reportaron $55 \%$ de ovejas en anestro al sur(14). Dichas variaciones pueden estar relacionadas con: 1) diferencias en la latitud entre los lugares de estudio y 2) el uso del macho celadores como técnica para detección de estro. Valencia et al(16) mencionan que la presencia del macho durante la detección de estros ejerce un efecto estimulatorio sobre la actividad estral de ovejas Pelibuey.
(Figure 5). The percentage of ewes in estrous was lower $(P<0.05)$ from J anuary to J une $(45.4$ to $81.8 \%$ ) that from July to December (100\%). The lowest presence of ewes in estrous was detected in May $(\mathrm{P}<0.05 ; 45.4 \%)$. Similarly, studies of the Southern(14), Central(5) and Northeast of Mexico(4), have reported a reduction in the estrous activity of Pelibuey ewes during the months of January to June, being most marked at the spring season. The results found in this study of estrous activity in the first half of the year, may be directly related to the sensitivity that may present some Pelibuey ewes to changes in the photoperiod(14,15). In addition, previously published studies were conducted in regions where latitude was less than in the region where the present study was developed. A hypothesis to be tested in this study was that high summer temperatures registered in the Northwestern of Mexico could be a factor that negatively altered estrous behavior in Pelibuey ewes, however, the results showed that the hypothesis is false, since $100 \%$ of ewes presented estrous from July to September. De la Isla et al(14), confirm that the high temperatures are not an environmental factor that condition estrous activity in Pelibuey ewes.

It is worth mentioning that there is a marked variation between studies on the percentage of Pelibuey ewes in anestrous during the season of low reproductive activity. In the Mexican Highlands reported between 0 and $23.1 \%$ of adult ewes in anoestrus(16), to the Northeast of the country found between 42 and $76 \%$ of anestric ewes( 4$)$, and recently, reported $55 \%$ of ewes in anoestrus at South(14). These variations may be related with: 1 ) difference in latitudes between the study sites and 2) the use of teaser rams as a technique for estrous detection. Valencia et al(16) mentioned that the presence of the ram during estrus detection has an stimulatory effect on the estrous activity of Pelibuey ewes.

Interestingly, it was noted that 7 (31.8\%) ewes cycled continuously and 4 (18.2\%) presented 
Interesantemente se observó que 7 (31.8 \%) ovejas ciclaron de forma continua y 4 (18.2\%) presentaron solamente anestro en un mes (Figura 6). En el altiplano Mexicano también reportaron dicho hallazgo en algunas ovejas Pelibuey (38.5\%(16) y $60 \%(5)$ ). Considerando que el Valle de Mexicali se ubica a una latitud de 32 o y el altiplano Mexicano a 190, y en ambos lugares se han encontrado ovejas ciclando continuamente, se podría inferir que al menos el $30 \%$ de las ovejas Pelibuey son insensibles a los cambios naturales del fotoperiodo que se registran durante el año, cuando menos bajo condiciones de México. Esta característica reproductiva podría ser utilizada para establecer programas de selección genética y mejorar la productividad de los rebaños nacionales de ovinos Pelibuey.

La duración del estro fluctuó entre los meses del año, pero en ninguno se observó una duración mayor a 48 h (Cuadro 1). Un mayor $(\mathrm{P}<0.05)$ porcentaje de ovejas presentaron estros cortos ( $<24 \mathrm{~h}$ ) en febrero $(64.8 \%)$ y marzo (47.0\%), mientras que en junio $(50.0 \%)$ y agosto $(45.4 \%)$ la mayoría $(P<0.05)$ de las ovejas presentaron estros largos (>36 y <48 h).

Figura 6. Distribución individual de la presencia de estros a través del año en ovejas Pelibuey

Figure 6. Individual distribution of the presence of estrous across the year in Pelibuey ewes

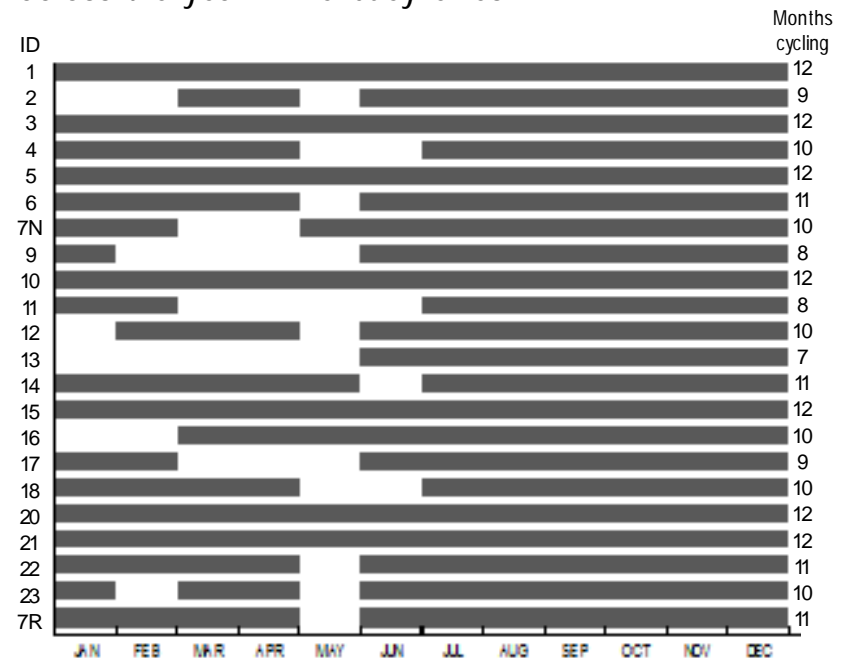

only anestrus in a month (Figure 6). In the Mexican Highlands also reported that finding in some Pelibuey ewes (38.5\%(16) and $60 \%(5)$ ). Given that the Mexicali Valley is located at a latitude of $32^{\circ}$ and Mexican Highlands to $19^{\circ}$, and in both places found ewes continuously cycling, we could infer that around $30 \%$ of Pelibuey ewes are insensitive to the natural changes in photoperiod that occur during the year, at least under Mexico conditions. This reproductive feature could be used to establish genetic selection programs and improve the productivity of the national Pelibuey sheep flock.

The estrous duration fluctuated between the months of the year, but none was observed longer than $48 \mathrm{~h}$ (Table 1$)$. A greater $(\mathrm{P}<0.05)$ percentage of ewes showed short estrous (< 24 h) in February (64.8\%) and March (47.0\%), while in June (50.0\%) and August (45.4\%) most $(\mathrm{P}<0.05)$ of ewes showed long estrous (>36 and <48 h). In the rest of the months, the sheep usually presented estrous classified as normal duration ( $>24$ and $<36 \mathrm{~h}$ ). These changes in the estrous duration in some months

Cuadro 1. Distribución mensual de las ovejas en estro dentro de los diferentes periodos de duración de estro

Table 1. Monthly distribution of ewes in estrus within the different periods of estrus duration

\begin{tabular}{lcccc}
\hline & $\mathrm{N}$ & $<24 \mathrm{~h}$ & $>24<36 \mathrm{~h}$ & $>36<48 \mathrm{~h}$ \\
\hline January & 18 & $33.3^{\mathrm{a}}$ & $55.5^{\mathrm{b}}$ & $11.2^{\mathrm{c}}$ \\
February & 17 & $64.8^{\mathrm{a}}$ & $17.6^{\mathrm{b}}$ & $17.6^{\mathrm{b}}$ \\
March & 17 & $47.0^{\mathrm{a}}$ & $23.5^{\mathrm{b}}$ & $29.5^{\mathrm{b}}$ \\
April & 17 & $29.4^{\mathrm{a}}$ & $35.3^{\mathrm{a}}$ & $35.3^{\mathrm{a}}$ \\
May & 10 & $20.0^{\mathrm{a}}$ & $60.0^{\mathrm{b}}$ & $20.0^{\mathrm{a}}$ \\
June & 18 & $28.9^{\mathrm{a}}$ & $21.1^{\mathrm{a}}$ & $50.0^{\mathrm{b}}$ \\
July & 22 & $22.7^{\mathrm{a}}$ & $50.0^{\mathrm{b}}$ & $27.3^{\mathrm{a}}$ \\
August & 22 & $27.3^{\mathrm{a}}$ & $27.3^{\mathrm{a}}$ & $45.4^{\mathrm{b}}$ \\
September & 22 & $9.1^{\mathrm{a}}$ & $63.6^{\mathrm{b}}$ & $27.3^{\mathrm{c}}$ \\
October & 22 & $9.1^{\mathrm{a}}$ & $59.1^{\mathrm{b}}$ & $31.8^{\mathrm{c}}$ \\
November & 22 & $9.1^{\mathrm{a}}$ & $59.1^{\mathrm{b}}$ & $31.8^{\mathrm{c}}$ \\
December & 22 & $18.2^{\mathrm{a}}$ & $50.0^{\mathrm{b}}$ & $31.8^{\mathrm{a}}$ \\
\hline a,b,c Values & with diverse superscript in rows are different \\
(P<0.05). & \multicolumn{4}{l}{}
\end{tabular}


En el resto de los meses, las ovejas presentaron generalmente estros clasificados como de duración normal (>24 y <36 h; P<0.05). Estas alteraciones en la duración del estro en algunos meses del año pueden estar relacionados con dos factores ambientales principalmente, las temperaturas altas y el fotoperiodo. En el Valle de Mexicali, las temperaturas de verano llegan a ser superiores a los $40^{\circ} \mathrm{C}$, y la diferencia en la cantidad de horas luz entre el día más corto (21 de diciembre [10 h]) y más largo (21 de junio [14.2 h]) a través del año es de $4 \mathrm{~h}$ y 18 min. Así, la presencia de estros cortos en febrero y marzo pueden deberse al fotoperiodo, esto considerando que de septiembre a enero las ovejas presentaron predominantemente estros normales. Dichos meses se caracterizan por un descenso en la cantidad de horas luz en el día, lo cual favorece la actividad sexual en las ovejas. En un estudio(14) realizado al sur del país, reportaron menor cantidad de folículos $\geq 4 \mathrm{~mm}$ entre los meses de febrero a mayo comparado con los meses de agosto a noviembre, lo cual repercute directamente en la concentración de estradiol circulante, y por consecuencia, en la duración de los signos de estro. Por otra parte, la presencia de estros largos en junio y agosto pueden deberse a las temperaturas altas que prevalecen durante la época de verano en la región de Mexicali(17). No obstante, los niveles de estrógenos y la dinámica folicular no fueron medidos en este estudio, por lo cual futuras investigaciones deben dirigirse a dar respuesta al porqué las ovejas Pelibuey presentan fluctuaciones en la duración de estro en algunos meses del año.

En conclusión, las ovejas Pelibuey reducen su actividad estral de enero a junio bajo las condiciones áridas del noroeste de México. Asimismo, en dicha región, las altas temperaturas prevalecientes en verano parecen no ser un factor que condicione la presencia de estro en esta raza de ovinos, pero pudiera estar interfiriendo con la duración del mismo. Finalmente, se encontró que cierta proporción de ovejas Pelibuey ( $32 \%$ ) son insensibles al fotoperiodo natural registrado a los $32^{\circ}$ de latitud norte. of the year can be related to two environmental factors mainly, high temperatures and photoperiod. In the Mexicali Valley, summer temperatures become higher than $40{ }^{\circ} \mathrm{C}$, and the difference in the amount of light between the shortest day (December 21 [10 h]) and the longest day (J une 21 [14.2 h]) throughout the year is $4 \mathrm{~h}$ and $18 \mathrm{~min}$. Thus, the presence of short estrous in February and March may be due to photoperiod, this considering that from September to January the sheep had predominantly normal estrus. These months are characterized by a decrease in the number of daylight hours, which stimulates the sexual activity in ewes. In a study done in the South of the country(14), reported fewer follicles $\geq 4$ $\mathrm{mm}$ between months of February to May compared with months of August to November, which has a direct impact on the concentration of circulating estradiol, and consequently, on the duration of the signs of estrous. On the other hand, the presence of long estrous in June and August may be due to the high temperatures that prevail during the summer in the Mexicali region(17). However, estrogen levels and follicular dynamics were not measured in this study, by which future research should be directed to respond why Pelibuey ewes show fluctuations in the estrous duration in some months of the year.

In conclusion, Pelibuey ewes reduced their estrous activity from January to J une under arid conditions of the Northwestern of Mexico. Also, in this region, the high temperatures prevailing in summer seem to not be a factor that conditions the presence of estrous in this sheep breed, but could be interfering with the duration of the same. Finally, it was found that certain proportion of Pelibuey ewes ( $32 \%)$ are insensitive to the natural photoperiod registered to the $32^{\circ}$ of North latitude.

\section{ACKNOWLEDGEMENTS}

We thank to PROMEP by financial support within the "Call to news PTC 2010", to carry out this 


\section{AGRADECIMIENTOS}

Agradecemos a PROMEP por el financiamiento otorgado dentro de la "Convocatoria de Apoyo a los Nuevos PTC 2010", para la realización de esta investigación. Asimismo, Miguel A. GastelumDelgado agradece a CONACYT el haberlo becado en sus estudios de Doctorado en Ciencias.

\section{LITERATURA CITADA}

1. Cerna C, Porras A, Valencia MJ, Perera G, Zarco L. Effect of an inverse subtropical $\left(19013^{\prime} \mathrm{N}\right)$ photoperiod on ovarian activity, melatonin and prolactin secretion in Pelibuey ewes. Anim Reprod Sci 2000;60-61(1):511-525.

2. Arroyo J . Estacionalidad reproductiva de la oveja en México. Trop Subtrop Agroecosyst 2011;14(3):829-845.

3. Porras AA, Zarco QLA, Valencia MJ. Estacionalidad reproductiva en ovejas. Ciencia Vet 2003;9(4):1-34.

4. González A, Murphy BD, Foote WC, Ortega E. Circannual estrous variations and ovulation rate in Pelibuey ewes. Small Ruminant Res 1992;8(3):225-232.

5. Arroyo LJ, Gallegos-Sánchez J, Villa-Godoy A, Berruecos JM, Perera G, Valencia J. Reproductive activity of Pelibuey and Suffolk ewes at 19o north latitude. Anim Reprod Sci 2007; 102(1):24-30.

6. Avendaño L, Álvarez FD, Salomé J, Correa A, Molina L, Cisneros FJ. Evaluación de algunos rasgos productivos del borrego Pelibuey en el noroeste de México. Resultados preliminares. Rev Cub Cienc Agri 2004;38(2):131-136.

7. Marai, IFM., El-Darawany, AA, Fadiel, A, Abdel-Hafez, MAM. Reproductive performance traits as affected by heat stress and its alleviation in sheep. Trop Subtrop Agroecos 2008; 8(3):209-234.

8. García E. Modificaciones al sistema de clasificación climática de Koppen. 3a ed. México, DF: Universidad Nacional Autónoma de México; 1985. research. Likewise, Miguel A. Gastelum Delgado thanks to CONACYT to grant a scholarship for their doctoral studies.

End of english version

9. Russel AJ F, Doney JM, Gunn RJ. Subjective assessment of body fat in live sheep. J Agric Sci 1969;72:451-454.

10. Hahn GL. Dynamic responses of cattle to thermal heat loads. J Dairy Sci 1999;82(Suppl 2):10-20.

11. SAS. SAS/STAT, user 's Guide (release 9.2). Cary, NC, USA: SAS Inst. Inc. 2004.

12. LPHSI. Livestock and Poultry Heat Stress Indices. The livestock and poultry heat stress indices for cattle, sheep and goats. Cited in the Agric Engineering Tech Guide. Clemson University, Clemson, SC, USA. 1990.

13. Heredia AM. Determinación de la época de menor actividad estral de las ovejas Pelibuey en el trópico [tesis de Maestría]. México, DF: Universidad Nacional Autónoma de México; 1994.

14. De la Isla HG, Aké LJ R, Avala BA, González-Bulnes A. Efecto de la condición corporal y la época del año sobre el ciclo estral, estro, desarrollo folicular y tasa ovulatoria en ovejas Pelibuey mantenidas en condiciones de trópico. Vet Méx 2010; 41(3): 167-175.

15. Cerna CC, Porras AA, Zarco QLA, Valencia MJ. Efecto del fotoperiodo artificial sobre el reinicio de la actividad ovárica postparto en la oveja Pelibuey. Vet Méx 2004;35(3):179185.

16. Valencia J, Porras A, Mejía O, Berruecos JM, Trujillo J, Zarco L. Actividad reproductiva de la oveja Pelibuey durante la época del anestro: Influencia de la presencia del macho. Rev Cient 2006; 16(2):136-141.

17. Jordan ER. Effects of heat stress on reproduction. J Dairy Sci 2003; 86:E104-E114. 